\title{
Field Efficacy Evaluation of some Ethnomedicinal Plants Smoke Repellency Against Anopheles arabiensis and Aedes Aaegypt
}

\author{
Abenezer Wendimu \\ Wolaita Sodo University \\ Wondimagegnehu Tekalign ( $\nabla$ wondex_2006@yahoo.com ) \\ Wolaita Sodo University https://orcid.org/0000-0002-4721-7528
}

\section{Research}

Keywords: Household Protection, Malaria Prevention, Mosquito Bites, Plant-Based Products, Vector-Borne Diseases

Posted Date: June 22nd, 2020

DOl: https://doi.org/10.21203/rs.3.rs-37049/v1

License: (1) (1) This work is licensed under a Creative Commons Attribution 4.0 International License. Read Full License 


\section{Abstract}

Background: Plant products can either be used as an insecticide to kill larvae or adult mosquitoes or as defensive repellents against mosquito bites; depending on the type of activity they have. A present study was carried out to determine the repellence of smoke prepared from burning the plants in a traditional way in order to reduce human-mosquito.

Methods: The candidate plant species (Azadirachta indica, Eucalyptus camaldulensis, and Ocimum forskolin) leave was grounded and mixed together in an equal amount. The mixed plant powders were checked by the thermal expulsion and burning on the traditional stoves in the field against two important malaria vectors (Anopheles arabiensis and Aedesaegypt). A four-by-four Latin-square design was used to randomly assign treatment and control experimental huts over different nights. In the treatment and control huts, the percentage repellence of the candidate plants mixed powder smoke on mosquito was determined from mosquito catches.

Results: On direct burning of the plants' powder, the highest percentage repellency for An. arabiensis $(94.7 \%, \mathrm{P}<0.001)$ and Aedesaegypt $(88.4 \%, \mathrm{P}<0.001)$ recorded. On thermal expulsion also the highest against $A n$. arabiensis ( $89 \%, \mathrm{P}<0.001)$ and against Aedesaegypt $(92 \%, \mathrm{P}<0.001)$ were recorded. The plants' mixed powder tested by both methods of application offered significant protection $(>85 \%)$ against two important mosquito species and thus has the potential to be used at least as an alternative way to control mosquito infestation in an easy manner in economic level.

Conclusion: The two methods of application may offer cost-efficient alternatives as additional household protection and as a helpful addition to bed nets, especially for the early part of the evening before bedtime.

\section{Background}

Insects are known to cause humans, animals, and plants extensive damage. The planet has well over 1 million different recognized insect species, and it is estimated that there could be as many as 10 million [1]. Mosquitoes represent the primary vector for the spread of diseases to more than 70 billion people every year around the world [2]. According to reports from the World Health Organization, malaria alone kills 30 million people per year [3]. Mosquitoes spread the arboviruses that cause yellow fever, dengue hemorrhagic fever, epidemic polyarthritis, and various forms of encephalitis [4]. Malaria kills 3 million people per year worldwide, including 1 child every 30 seconds [5]. An efficient vaccine has not been available for protection from these diseases still now, except that of yellow fever and Japanese encephalitis. Therefore, protection from mosquito bites is one of the best strategies to prevent these diseases or reduce their incidence.

DDT (dichlorodiphenyltrichloroethane) is a toxin that used widely to get rid of insects such as mosquitoes in Ethiopia. In the country, the use of DDT in malaria prevention has resulted in tremendous hope as the pesticide has been shown to be highly effective in killing the malaria vectors and interrupting their 
transmission due to its spatial repellence and annoying effect. In the environment however, $p, p^{\prime}$-DDT is degraded into $p, p^{\prime}$-DDE (1,1-Dichloro-2,2-bis(4-chlorophenyl)ethylene) and $p, p^{\prime}$-DDD (1,1-Dichloro-2,2-bis(4chlorophenyl)ethane), in which $p, p^{\prime}$-DDE being more persistent than the parent compound. This persistence, caused by its high lipophilicity and low reactivity, provides the conditions necessary for bioaccumulation in organisms and biomagnification in food webs. In such a way, DDT is highly toxic to aquatic organisms, fish and amphibians, and carcinogenic and mutagenic effects in other non-target organisms $[6,7]$. DDE, the main DDT metabolite, causes embryo deaths in predatory birds by thinning the eggshell [6, 8]. Lifetime DDT therapy caused a dose-related liver tumor in mice. DDT also increased lung tumor incidences in another mice study. DDE and DDD in mice are also carcinogenic [9]. According to Chen et al. [10], DDT and its metabolites have estrogenic activity and DDE has been shown to act as an androgen antagonist [11].

In the past few years, to overcome this problem, thousands of plants have been tested as sources of insect repellents or killers. Citronella, neem, cedar, verbenas, pennyroyal, geranium, lavender, pines, cajuput, catnip, cinnamon, rosemary, basil, thyme, allspice, garlic, and peppermint plants have been identified by means of both grassroots and scientific investigations against various hematopoietic arthropods [12,13]. Smoke from some plants acts to repel Anopheles mosquitoes: $90.1 \%$ by Ostostegiaintegrifolia [14, 15], $79.8 \%$ by Olea europaea and $44.5 \%$ by Ocimum suave $[16,17]$. The leaves of Ocimumcanum provided $63.6 \%$ protection from mosquito bites when hung fresh in the homes in Guinea Bissau, West Africa [18].

In addition to the harmful effects of synthetic products mentioned above, the malaria vectors in Ethiopia are currently developing high to moderate levels of DDT resistance and some other pyrethroids [19]. Plant-based products are believed to be safer than synthetic insecticides [20,21]. However, plant-based products have so far received little attention in Ethiopia despite the other world. This study was carried out in this regard to evaluate the field efficacy of some ethnomedicinal plants smoke repellency against Anopheles arabiensis and Aedes aegyptby direct burning and thermal expulsion application methods in the Diguna Fango District, Wolaita, Ethiopia.

\section{Methods}

\section{Study area}

The study was conducted in small villages of Diguna Fango District located at $8.25^{\prime} \mathrm{N}$ and $39^{\prime} 01^{\prime} \mathrm{E}$ in Southern Region, Wolaita zone, Ethiopia. The area is located about $95 \mathrm{~km}$ south of the capital Addis Ababa, and $63 \mathrm{~km}$ from east of Wolaita Sodo town, where the Bilate River crosses the main road to Sidama, Ethiopia at an altitude of $1700 \mathrm{~m}$ above sea level. The Bilate River during the rainy season creates swampy and more or less permanent large pools of water. The average annual rainfall and temperature of the area are about $700 \mathrm{~mm}$ and $21^{\circ} \mathrm{C}$, respectively.

\section{Test plants}


Due to their bioactive compound content and various reports on their traditional uses as an effective vector repelling function, three candidate plant species (Azadirachta indica, Eucalyptus camaldulensis, and Ocimum forskolin) were selected for field efficacy studies [22-23, 16].

\section{Preparation of plants for smoke toxicity test}

The dried candidate plant species leave was collected and ground by grinder mill. Then, thoroughly mixed evenly and made available for experimentation.

\section{Experimental houses selection}

To study the repulsing effect of the smoke from three candidate plant species mixed powder on mosques, eight traditional village houses (huts) were selected from two nearby kebeles (small units of Districts); such as Fango Boloso and Fango Ofa randomly four from each of them in $20 \mathrm{~m}$ intervals. Four huts were used to determine the field efficacy of plants by direct burning and the other four were used to determine the efficacy of the application of plants by thermal expulsion. All experimental huts were mud-walled with grass-thatched roofs ('Sar-bet' in the Amharic language, which is the national official language of Ethiopia) in which open eaves, unscreened small holes, and doors allow ready access to mosquitoes from the shoreline of river Bilate which is extremely infested with mosquitoes and necessarily common area for their reproduction.

\section{Repellency tests}

Field evaluation of plant powder smoke repellency was performed with 3 local volunteers (only males between 15 and 25 years of age) who participated in the experimentation. On selected experimental huts, pre-weighted plants powder was put on top of a thin hot metal plate which was placed immediately above the burning charcoal in the traditional stove for thermal expulsion method and for direct smoking method; the plant powder was placed directly on the burning charcoal according to the work of Seyoum et al. $[22,16]$. The huts were fumigated by the smoke from 7:00 p.m. to 11:00 p.m. The volunteers were sat on chairs in the treatment huts in liner by the 1-meter interval between them and collected all of the mosquitoes landing on their legs and arms for a 20 minute. Each exposure period was followed by a 5 min break before the next mosquito collection was conducted. Thus, on the first night, subjects wearing a T-shirt and shorts trousers exposed their untreated arms and legs to assess the density of biting/landing mosquitoes. The subjects (volunteers) were continuously exposed to the biting mosquito while adding $50 \mathrm{~g}$ of the powder directly on the traditional stove (for direct burning) and collected mosquitoes landing on exposed parts of the body using small test tubes and torchlight while being supervised by the investigators.

The same procedure was followed to check for thermal expulsion. In the case of thermal expulsion, the powder was put on top of a thin metal strip placed immediately above the lightened charcoal. The experimentation was carried out for about four hours. As a precaution, mosquitoes were immediately removed after landing, before the commencement of feeding. The hourly collections of each volunteer were counted and grouped the removed mosquitoes during the fumigation of individual huts by both 
methods of application based on their morphological difference for species identification. Mosquitoes have been characterized by morphological properties at the species level [24]. A four-by-four Latin-square design was used for both experiments in three treatment huts and one hut with only burning charcoal stove without any smoke treatment to serve as a control. The treatment and control huts were randomly assigned by rotation in consecutive treatment nights. The tests were carried out with an intervening period of one night to avoid the potential residual effect of the plants by periodic thermal expulsion and direct smoking. The tests were replicated for four treatment nights for both thermal expulsion and direct burning experiments.

\section{Data analysis}

The overall repellent effect of the smoke from the mixed powder of the plants was analyzed by allowing for the differences between experimental units by generalized linear modeling (ANOVA) of the relationship between mosquito collections in control $(C)$ and in treatment huts $(T)$. The repellence index (R) was estimated as $\% R=(C-T) / C \times 100 \%$, where $C$ and $T$ are the mean number of mosquitoes landing on the control and the treatment hunts, respectively [25]. Tukey's test was conducted to compare responses to the smoke repellency in the landing assays by using Minitab ${ }^{\circledR} 18$ statistical packages for Windows, version 10.

\section{Results}

The overall repulsive effect of the smoke over the four treatment nights in individual huts by two methods of application and the relative repelling effect of smoke by direct burning against two biting mosquito species (Aedes aegypt and An. arabiensis) over four treatment nights are shown in Table 1 and 2 below. The comparative repelling efficacy of smoke against two biting mosquito species (Aedes aegypt and An. arabiensis) over four treatment nights by direct burning is shown in Table 2. It indicated that the reduction (\%) of mosquito landing within each treatment night was between $100 \%-89 \%$ for An. arabiensis and between $100 \%-75 \%$ for Aedes aegypt. Averagely the repellency was $94.5 \%$ and $87.5 \%$ respectively. In both species, however, the mean reductions (\%) of all treatments are not significantly different from each other $(p>0.05)$.

The relative repelling efficacy of smoke against two biting mosquito species (Aedes aegypt and An. arabiensis) over four treatment nights by thermal expulsion is shown in Table 3 below. The result has shown that the reduction (\%) of mosquito landing within each treatment night was between $97 \%-78 \%$ for An. arabiensis and between 100\%-88percent for Aedes aegypt. Averagely the repellency was $87.5 \%$ and $94 \%$ respectively. In both species, however, the mean reduction (\%) of all treatments is not significantly different from each other $(p>0.05)$. 
Table 1

The overall repulsive effect of the smoke over four treatment nights in individual huts by two methods of application

\begin{tabular}{|c|c|c|c|c|c|c|}
\hline \multirow[t]{2}{*}{ Huts } & \multirow[t]{2}{*}{ Species } & \multicolumn{4}{|c|}{$\begin{array}{l}\text { Total number of mosquitoes fed on volunteers over four treatment } \\
\text { nights in individual huts }\end{array}$} & \multirow[t]{2}{*}{$\begin{array}{l}\text { Mean } \pm \\
\text { SE }\end{array}$} \\
\hline & & 1 & 2 & 3 & 4 & \\
\hline \multirow[t]{2}{*}{$A_{1}$} & $\begin{array}{l}\text { An. } \\
\text { arabiensis }\end{array}$ & 0 & 1 & 0 & 2 & $\begin{array}{l}0.75 \pm \\
0.47\end{array}$ \\
\hline & $\begin{array}{l}\text { Aedes } \\
\text { aegypt }\end{array}$ & 0 & 0 & 0 & 0 & $\begin{array}{l}0.00 \pm \\
0.00\end{array}$ \\
\hline \multirow[t]{2}{*}{$\mathrm{B}_{1}$} & $\begin{array}{l}\text { An. } \\
\text { arabiensis }\end{array}$ & 1 & 2 & 0 & 0 & $\begin{array}{l}0.75 \pm \\
0.47\end{array}$ \\
\hline & $\begin{array}{l}\text { Aedes } \\
\text { aegypt }\end{array}$ & 0 & 1 & 3 & 0 & $\begin{array}{l}1.00 \pm \\
0.70\end{array}$ \\
\hline \multirow[t]{2}{*}{$\mathrm{C}_{1}$} & $\begin{array}{l}\text { An. } \\
\text { arabiensis }\end{array}$ & 0 & 0 & 0 & 0 & $\begin{array}{l}0.00 \pm \\
0.00\end{array}$ \\
\hline & $\begin{array}{l}\text { Aedes } \\
\text { aegypt }\end{array}$ & 1 & 0 & 0 & 0 & $\begin{array}{l}0.25 \pm \\
0.25\end{array}$ \\
\hline \multirow[t]{2}{*}{$\mathrm{D}_{1}$} & $\begin{array}{l}\text { An. } \\
\text { arabiensis }\end{array}$ & 39 & 28 & 17 & 30 & $\begin{array}{l}28.5 \pm \\
4.51\end{array}$ \\
\hline & $\begin{array}{l}\text { Aedes } \\
\text { aegypt }\end{array}$ & 16 & 8 & 12 & 7 & $\begin{array}{l}10.75 \pm \\
2.00\end{array}$ \\
\hline \multirow[t]{2}{*}{$\mathrm{A}_{2}$} & $\begin{array}{l}\text { An. } \\
\text { arabiensis }\end{array}$ & 2 & 1 & 0 & 0 & $\begin{array}{l}0.75 \pm \\
0.47\end{array}$ \\
\hline & $\begin{array}{l}\text { Aedes } \\
\text { aegypt }\end{array}$ & 1 & 0 & 1 & 0 & $\begin{array}{l}0.50 \pm \\
0.28\end{array}$ \\
\hline \multirow[t]{2}{*}{$\mathrm{B}_{2}$} & $\begin{array}{l}\text { An. } \\
\text { Arabiensis }\end{array}$ & 0 & 1 & 3 & 0 & $\begin{array}{l}1.00 \pm \\
0.28\end{array}$ \\
\hline & $\begin{array}{l}\text { Aedes } \\
\text { aegypt }\end{array}$ & 0 & 0 & 0 & 1 & $\begin{array}{l}0.25 \pm \\
0.25\end{array}$ \\
\hline \multirow[t]{2}{*}{$\mathrm{C}_{2}$} & $\begin{array}{l}\text { An. } \\
\text { Arabiensis }\end{array}$ & 2 & 1 & 1 & 1 & $\begin{array}{l}1.25 \pm \\
0.25\end{array}$ \\
\hline & $\begin{array}{l}\text { Aedes } \\
\text { aegypt }\end{array}$ & 0 & 0 & 0 & 1 & $\begin{array}{l}0.25 \pm \\
0.25\end{array}$ \\
\hline \multirow[t]{2}{*}{$\mathrm{D}_{2}$} & $\begin{array}{l}\text { An. } \\
\text { Arabiensis }\end{array}$ & 23 & 31 & 19 & 36 & $\begin{array}{l}27.25 \pm \\
3.83\end{array}$ \\
\hline & $\begin{array}{l}\text { Aedes } \\
\text { aegypt }\end{array}$ & 10 & 11 & 13 & 17 & $\begin{array}{l}12.75 \pm \\
1.54\end{array}$ \\
\hline SE: & dard error & & & & & \\
\hline
\end{tabular}


$A_{1}-C_{1}:$ Treatment huts (direct burning)

$A_{2}-C_{2}:$ Treatment huts (thermal expulsion)

$\mathrm{D}_{1}$ : Control huts (direct burning)

$\mathrm{D}_{2}$ : Control huts (direct burning)

Table 2

The relative repelling effect of smoke by direct burning against two biting mosquito species (Aedes aegypt and An. arabiensis) over four treatment nights

\begin{tabular}{|llllll|}
\hline Species & \multicolumn{4}{l}{ Reduction (\%) of mosquito bites over four treatment nights (95\% Cl) } & P-value* \\
\cline { 2 - 5 } & $\mathbf{1}$ & $\mathbf{2}$ & $\mathbf{3}$ & $\mathbf{4}$ & \\
\hline An. arabiensis & 97 & 89.3 & 100 & 93.3 & $\mathrm{p}>0.05$ \\
\hline Aedes aegypt & 93.75 & 87.5 & 75 & 100 & $\mathrm{p}>0.05$ \\
\hline *P-Value obtained from Tukey's test at $\mathrm{a}=0.05$ & & & \\
\hline
\end{tabular}

Table 3

The relative repelling efficacy of smoke against two biting mosquito species (Aedes aegypt and An. arabiensis) over four treatment nights by thermal expulsion

\begin{tabular}{|llllll|}
\hline Species & \multicolumn{4}{l}{ Reduction (\%) of mosquito bites over four treatment nights (95\% Cl) } & P-value* \\
\cline { 2 - 5 } & $\mathbf{1}$ & $\mathbf{2}$ & $\mathbf{3}$ & $\mathbf{4}$ & \\
\hline An. arabiensis & 82.6 & 90.3 & 78.9 & 97.2 & $\mathrm{p}>0.05$ \\
\hline Aedes aegypt & 90 & 100 & 92.3 & 88.2 & $\mathrm{p}>0.05$ \\
\hline *P-Value obtained from Tukey's test at $\mathrm{a}=0.05$ & & & \\
\hline
\end{tabular}

The average number of mosquitoes collected over four nights, in both treatment as well as control huts and the mean smoke repellency index (R) of two biting insect species (Aedes aegypt and An. arabiensis) by direct burning are shown in Table 4. As shown, the mean repellency index (R) of the smoke against $A n$. arabiensis was $94.73 \%$ and against Aedes aegypt was $88.4 \%$. In the comparison of repellency between treatment and control groups, mosquito landing on treatment groups was reduced significantly $(p<0.05)$ and there were no significant reductions observed in control landings. 
Table 4

The mean repellence index $(R)$ of mosquitoes landing on the control and the treatment hunts by direct burning

\begin{tabular}{|lllll|}
\hline $\begin{array}{l}\text { The mosquito } \\
\text { species }\end{array}$ & Conditions & $\begin{array}{l}\text { Mean number } \\
\text { collected }\end{array}$ & $\begin{array}{l}\text { The mean repellence index } \\
\mathbf{( R )}\end{array}$ & $\begin{array}{l}\text { P- } \\
\text { Value* }\end{array}$ \\
\hline An. arabiensis & Treatment & 1.5 & 94.73 & $\mathrm{p} \otimes 0.05$ \\
\hline Aedes aegypt & Control & 28.5 & & $\mathrm{p} \otimes 0.05$ \\
\hline & Treatment & 1.25 & 88.4 & \\
\hline *P-Value obtained from Tukey's test at $\mathrm{a}=0.05$ & & & \\
\hline
\end{tabular}

The average number of mosquitoes collected over four nights, in both treatment as well as control huts and the mean smoke repellency index (R) of two biting insect species (Aedes aegypt and An. arabiensis) by thermal expulsion is shown at Table 5 below. As shown, the mean repellency index (R) of the smoke against An. arabiensis was $89 \%$ and against Aedes aegypt was $92 \%$. In the comparison of repellency between treatment and control groups, mosquito landing on treatment groups was reduced significantly $(p<0.05)$ and there were no significant reductions observed in control landings.

Table 5

The mean repellence index $(\mathrm{R})$ of mosquitoes landing on the control and the treatment huts by thermal expulsion

\begin{tabular}{|lllll|}
\hline $\begin{array}{l}\text { The mosquito } \\
\text { species }\end{array}$ & Conditions & $\begin{array}{l}\text { Mean number } \\
\text { collected }\end{array}$ & $\begin{array}{l}\text { The mean repellence index } \\
\mathbf{( R )}\end{array}$ & $\begin{array}{l}\text { P- } \\
\text { Value* }\end{array}$ \\
\hline An. arabiensis & Treatment & 3 & 89 & $\mathrm{p} \otimes 0.05$ \\
\cline { 2 - 5 } & Control & 27.25 & & $\mathrm{p} \otimes 0.05$ \\
Aedes aegypt & Treatment & 1 & 92 & \\
\cline { 2 - 4 } & Control & 12.75 & & \\
\hline *P-Value obtained from Tukey's test at $\mathrm{a}=0.05$ & & \\
\hline
\end{tabular}

The relative efficacies of the powder smoke against two mosquito species in both direct burning and thermal expulsion methods of applications were presented above in Table 4 and 5 . The provided an average repellence index $(\mathrm{R})$ of both species of mosquitoes landing indirect burning methods of application were $94.73 \%$ and $88.4 \%$, respectively, over four treatment nights. In the case of thermal explosion methods of application the mean repellency index (R) of the smoke against An. arabiensis was $89 \%$ and against Aedes aegypt was $92 \%$. The main species presented during the study period were Anopheles arabiensis and Aedes aegypt. Of the 342 mosquito species collected in four treatment nights, Anopheles arabiensis constituted the bulk of the collection (70\%), and Aedes aegypt [Rockefeller strain] comprised just $30 \%$. The smoke from plant powder was significantly reduced the number of mosquitoes 
$(p<0.05)$ in both methods of application compared to the control burning charcoal alone in the traditional stove. No significant difference $(p>0.05)$ was observed in the comparison between the two methods of application (direct burning and thermal expulsion) for both mosquito species under experimentation, although, the direct burning method appeared to be a little more efficient in repelling mosquitoes (94.73-88.4\% protection) than the thermal expulsion method of application ( $92-89 \%$ protection) as shown above in Tables 3 and 4.

\section{Discussion}

In Ethiopia, the use of repulsive plants to reduce human vector contact is common practice in village communities. Smoke is the most widely used means of repulsing mosquitoes. The major plants used as repellents are Ocimum species (Ocimum forskolin, Ocimum kilimandscharicum, and Ocimum suave), Eucalyptus species, Eucalyptus camaldulensis, Lantana camara, and Azadirachta indica. In this study, the repellent effect of the smoke from the leave of selected plant species (Azadirachta indica, Eucalyptus camaldulensis, and Ocimum forskolin) leave powder mixtures was evaluated against Aedes aegypt and An. arabiensis by direct burning and thermal expulsion methods of the application under normal field conditions. As shown in the result, the candidate test plants pose significant repellent effects both thermally expelled and directly burnt against Aedes aegypt and An. arabiensis as compared to the control of burning charcoal alone.

Plants may be alternative sources for mosquito repellent agents since they constitute a rich source of bioactive chemicals [26]. Plant products can either be used as an insecticide to kill larvae or adult mosquitoes or as defensive repellents against mosquito bites; depending on the type of activity they have [27]. Lemon eucalyptus (Corymbia citriodora), Eucalyptus camaldulensis, Ocimum suave, and Ocimum basilicum have been evaluated for their repellency by thermal expulsion of their leaves from traditional stoves against Anopheles arabiensis and Anopheles phronesis in traditional homesteads around Koka, the central part of Ethiopia [28]. In their report, Ocimum basilicum was found to be the most effective repellent plant against $A n$. arabiensis by the direct burning application method (73.11\%) followed by Ocimum suave (71.51\%), Corymbiacitriodora (70.59\%), and Eucalyptus camaldulensis (65.29\%). In the thermal expulsion method, similar results were obtained as Corymbiacitriodora (78.69\%) and Ocimum basilicum (78.66\%) showed similar repellency effects followed by Ocimum suave (73.55\%) and Eucalyptus camaldulensis (71.91\%) against An. arabiensis. All plant species also showed over $72 \%$ repellency by the thermal expulsion application method against An. phronesis. The same experiment was also carried out in traditional village houses in western Kenya to evaluate the repellency of Lemon eucalyptus (Corymbiacitriodora) and other repellent plants (Ocimum suave and $O$. Itilimandscharicum) against An. gambiae and An. funestus by thermal expulsion of their leaves from traditional stoves [16]. According to their report, the highest repellency of about $49 \%$ was recorded by Corymbiacitriodora against An. gambiae and only $15 \%$ repellency against An. funestus.

Our results of $94.73 \%$ repellency against $A n$. arabiensis and $88.4 \%$ against Aedes aegyptin a direct burning method, and $89 \%$ repellency against An. arabiensis and $92 \%$ against Aedes aegypt in thermal 
expulsion method were comparative with $78.69 \%$ repellency of Corymbiacitriodora against An. arabiensis in thermal explosion and $73.11 \%$ repellency of $O$. basilicum by direct smoking is significant and greater than those reported by Sisay et al. [28]. Corymbiacitriodora's highest repellence at $48.71 \%$ followed by an equal degree of repellence of $O$. kilimandscharicum and $O$. suave in thermal expulsions with $44.54 \%$ against An. gambiae and An. funestusis also comparative with the work of Seyom et al. [16]. Because under experimentation they evaluated single plant species repellence against the vector as a sole experimental source of data, however, the combined effect of different plant species repellence for the vectors understudy was evaluated in this research work.

Leaves of Corymbiacitriodora exhibited the highest repellency (51.3\%) by direct burning, followed by leaves of Lantana uckambensis (33.4\%) and, leaves and seeds of Ocimum suave $28.0 \%$. The combination of Ocimumkilimandscharicum with Lantana uckambensis repelled $54.8 \%$ of mosquitoes by thermal expulsion in the work of Seyom et al. [22]. Seyoum et al. [23] in their article performed similar experiments in a semi-field environment in western Kenya toward An. gambiae. They observed the highest repellence of $74.5 \%$ and $51.3 \%$ for Corymbiacitriodora by thermal expulsion and direct burning, respectively. Our results by thermal expulsion and direct burning in field situations against both Anopheles and Aedes species of mosquito in the study area were found to be significant and comparable to those observed by Seyoum et al. [22, 23]. Ocimumforskolei reduced biting by over $50 \%$ against $A n$. arabiensis under field conditions according to Waka et al. [29]. Ocimum suave and Ocimumkilimandscharium are used extensively in Tanzania and are highly effective in bioassays against a range of mosquito species as seen in Kweka et al. [30, 31]. In addition, there are reports of Ocimum spp. being used as mosquito repellents via burning or thermal expulsion [32].

There are well-established variations in the susceptibility of mosquito species to synthetic repellents like DEET [32]. DEET is a synthetic mosquito repellent widely used all over the world for protection against mosquito bites [33]. Because of concerns about the side effects of DEET, the U.S. Centres for Disease Control and Prevention (CDC) licensed plant-based mosquito repellents, one of which was paraMenthane-3,8-dio(PMD) [34]. In developed nations, PMD is successfully commercialized and is widely used [35]. Several plants and plant varieties are known to produce a range of oils and have already been shown to be effective mosquito repellents. Ongore et al. [36] surveyed a population in Kenya and found that $16 \%$ burned leaves of Lantana rhodesciense and $16 \%$ burned other waste plant materials including sisal leaves and rice husks. People burn orange peels in Sierra Leone and Ghana to flush away mosquitoes, while neem leaves (Azadirachta indica) and baobab tree (Adansoni adigitata) are burned in Ghana and Gambia [37]. The neem tree (Azadirachta indica) products were well-known for insect repellent and antifeedant properties long before the advent of synthetic insecticides and have already been documented using its various constituents in agriculture and other areas [38-40]. The burning of fresh and dried leaves from Lamiaceae, Poaceae, and Pinaceae around and within the home to provide protection against mosquito bites is widely used throughout rural Ethiopia [14, 15]. Some essential chemical components like eugenol, linalool, and methyl cinnamate have also been reported. These plants usually contain camphor and thymol and have mosquito repellent properties [41]. An essential oil from this plant repelled Aedes aegypti for about $75 \mathrm{~min}$ [32] and is also reported to have some insecticidal 
activity against a variety of insects [42]. It was also shown that Ocimum fors/tolei reduced the indoor biting levels of $A n$. arabiensis by $53 \%$ when its fresh leaves and shoots were hanging at the ends of the beds in Eritrea [29].

To our finding, no specific investigations were conducted to test the combined repelling effect of the mixed powder of the Azadirachta indica, Eucalyptus camaldulensis, and Ocimum forskoleito make a comparison, although both methods of application provided an important and significantly higher degree of repellence in comparison with other plant species reported (Tables 3 and 4). The higher percentage repellencies ( $>85 \%$ ) were generally observed in the present study might have some contributions from the burning charcoal itself used to smolder the plants. As we did in controlled huts, lightening charcoal only could have some degree of protection (approximately 20\%) from mosquitoes, probably by reducing humidity near the fire [18]. Assuming the same level of repellency from charcoal alone in the present study, the actual repellencies of the test plants could be greater than $65 \%$ by both methods of applications which still are comparative with work of Seyoum et al. [27] $(22-23,16)$ and Sisay et al. [28]. However, charcoal, firewood or dried cow dung are usually used in traditional stoves in Ethiopia to heat the desired plant parts or incense [28], so that the additional repellents provided by them would always be advantageous.

\section{Conclusions}

The repelling effects of selected plants viz. Azadirachta indica, Eucalyptus camaldulensis, and Ocimum forskolei leave powder are significantly reduced two species of mosquito biting. Such plants are readily available and their application methods being simple and affordable may be useful in protecting malaria. The community-wide use of such repellent plants has the potential to complement existing control measures, such as treating mosquito nets once a month in areas where affordability of the Insecticidetreated mosquito nets (ITNs) is restricted. The two methods of application may offer cost-efficient alternatives as additional household protection and as a helpful addition to bed nets, especially for the early part of the evening before bedtime.

\section{Declarations}

\section{Ethics approval}

This study conducted in accordance with the declaration of Helsinki that provides guidance for the researcher to protect research subjects. The study was approved by the Institutional Research Review Board (IRB) of Wolaita Sodo University.

\section{Consent to participation}

Not applicable

\section{Consent to publication}


All authors agreed to the public this original research work

\section{Data availability statement}

Data sharing not applicable to this manuscript as no datasets were generated or analyzed during the current study.

\section{Competing interests}

The authors declare that they have no competing interests

\section{Funding statement}

The authors declare that no specific funding from any fundraising organizations.

\section{Authors' contribution statement}

All authors contributed to the study conception and design. Material preparation, data collection, and analysis were performed by Abenezer Wendimu and Wondimagegnehu Tekalign. The first draft of the manuscript was written by Abenezer Wendimu and all authors commented on previous versions of the manuscript. All authors read and approved the final manuscript.

\section{Acknowledgments}

We would like to acknowledge Wolaita Sodo University for giving permission to do this research. We also thank the local communities and the local government officials for their help during the data collection period.

\section{References}

1. Nigel E, James M, Claire G, Andrew J. New approaches narrow global species estimates for beetles, insects, and terrestrial arthropods. PNAS. 2015;112(Suppl 24):7519-23.

2. WHO (World Health Organization). Vector-borne diseases: Main vectors and diseases they transmit. 2017. https://www.who.int/news-room/fact-sheets/detail/vector-borne-diseases. Accessed 24 Dec 2019.

3. WHO (World Health Organization). Malaria. 2019. https://www.who.int/news-room/factsheets/detail/malaria. Accessed 24 Dec 2019.

4. Mohd S, Shailja M. Combating Mosquito-Borne Lymphatic Filariasis with Genomics Technologies: Enabling Novel Drug Discovery for Neglected Tropical Diseases. Curr Pharmacogenomics Person Med. 2012;10(Suppl 2):148-58.

5. Shell ER. Resurgence of a Deadly Disease Malaria is coming to America with growing frequency-even as efforts at control remain virtually nonexistent, and a vaccine is at best a distant hope. Atlantic Boston. 1997;280:45-60. 
6. Lear LJ. Rachel Carson's Silent Spring. Environ Hist Rev. 1993;17:23-48.

7. Tatiana C. Toxicologically important DDT metabolites Synthesis, enantioselective analysis and kinetics. Doctoral Thesis, Stockholm University, Stockholm, Sweden; 2009. p. 1-55.

8. Helander B, Olsson A, Bignert A, Asplund L, Litzen K. The role of DDE, PCB, coplanar PCB and eggshell parameters for reproduction in the white-tailed sea eagle (Haliaeetus albicilla) in Sweden. Ambio 2002;31:386-403.

9. Turusov V, Rakitsky V, Tomatis L. Dichlorodiphenyltrichloroethane (DDT): Ubiquity, persistence and risks. Environ Health Perspect. 2002;110:125-8.

10. Chen C, Hurd C, Vorojeikina D, Arnold S, Notides A. Transcriptional activation of the human estrogen receptor by DDT isomers and metabolites in yeast and MCF-7 cells. Biochem Pharmacol. 1997;53:1161-72.

11. Kelce W, Stone C, Laws S, Gray L, Kemppainen J, Wilson E. Persistent DDT metabolite $p, p^{\prime}$-DDE is a potent androgen receptor antagonist. Nature. 1995;375:581-5.

12. Maia F, Moore J. Plant-Based Insect Repellents: A Review of Their Efficacy, Development and Testing. Malar J. 2011;10:11-25.

13. Carroll S, Loye J. PMD, a registered botanical mosquito repellent with deet-like efficacy. J Am Mosq Control Assoc. 2006;22 Suppl 3:507 - 14.

14. Karunamoorthi K, Ilango K, Endale A. Ethno-botanical survey of knowledge and usage custom of traditional insect/mosquito repellent plants among the Ethiopian Oromo ethnic group. J Ethnopharmacol. 2009a;125:224-9.

15. Karunamoorthi K, Mulelam A, Wassie F. Assessment of knowledge and usage custom of traditional insect/mosquito repellent plants in Addis Zemen Town, South Gander, North Western Ethiopia. J Ethnopharmacol. 2009b;121(Suppl 1):49-53.

16. Seyoum A, Killeen GF, Kabiru EW, Knols BG, Hassanali A. Field efficacy of thermally expelled or live potted repellent plants against African malaria vectors in western Kenya. Trop Med Int Health. 2003;8:1005-11.

17. Dugassa S, Medhin G, Balkew M, Seyoum A, Gebre-Michael T. Field investigation on the repellent activity of some aromatic plants by traditional means against Anopheles arabiensis and $A n$. Pharoensis (Diptera: Culicidae) around Koka, central Ethiopia. Acta Trop. 2009;112:38-42.

18. Moore S, Lenglet A, Hill N. Insect Repellents: Principles, Methods and Uses. Debboun M, Frances SP, Strickman D, editors. Boca Raton: CRC Press, Taylor and Francis Group; Plant-based insect repellents; 2006. pp. 275-303.

19. Meshesha B, Muntaser I, Lizette L, Basil D, Howard E, Abraham A, et al. Insecticide resistance in Anopheles arabiensis (Diptera: Culicidae) from villages in central, northern and south west Ethiopia and detection of kdr mutation. Parasites Vectors. 2010;3:40.

20. Regnault-Roger C, Vincent C, Arnason JT. Essential oils in insect control: Low-risk products in a high stakes world. Annu Rev Entomol. 2012;57:405-24. 
21. Wendimu A, Tekalign W. Infusion extraction of toxin from chili pepper (Capsicum baccatum) for bedbug protection. Asian J Biotechnol. 2020;12:65-74.

22. Seyoum K, Pålsson S, Kung'a E, Kabiru W, Lwande G, Killeen A, Hassanali B. Traditional use of mosquito-repellent plants in western Kenya and their evaluation in semi-field experimental huts against Anopheles gambiae: ethnobotanical studies and application by thermal expulsion and direct burning. Trans R Soc Trop Med Hyg. 2002a;;96(3):225-31.

23. Seyoum A, Kabiru E, Wande W, Killeen G, Hassanali A, Knols B. Repellency of live potted plants against Anopheles gambiae from human baits in semi-field experiments huts. Am J Trop Med Hyg. 2002b;67:191-5.

24. Gillies M, Coetzee M. A supplement to the Anophelinae of Africa South of the Sahara. So Afr Inst Med Res Pubs. 1987;55:1-143.

25. Yap H. Effectiveness of soap formulations containing deet and permethrin as personal protection against outdoor mosquitoes in Malaysia. J Am Mosq Control Assoc. 1986;2:63-7.

26. Wink M. Protection and application of phytochemicals from an agricultural perspective. Phytochemistry Agric. 1993;34:171.

27. ICMR (Indian Council of Medicinal Research). Prospects of using herbal products in the control of mosquito vectors. ICMR Bulletin. 2003;33:1-12.

28. Sisay D, Girmay M, Meshesha B, Alzlilu SC, Teshome GM. Field investigation on the repellent activity of some aromatic plants bytraditional means against Anopheles arabiensis and An. Pharoensis (Diptera: Culicidae) around IColza, central Ethiopia. Acta Trop. 2009;112:38-42.

29. Waka M, Hopkins R, Curtis C. Ethno-botanical survey and testing of mosquito repellent plants traditionally used in Eritrea. J Ethnopharmocol. 2004;95:95-101.

30. Kweka EJ, Mosha F, Lowassa A, Mahande AM, Kitau J, Matowo J, et al. Ethno-botanical study of some of mosquito repellent plants in north-eastern Tanzania. Malar J. 2008a;;7:151-9.

31. Kweka E, Mosha W, Lowassa A, Mahande A, Mahande M, Massenga C, et al. Longitudinal evaluation of Ocimum and other plants effects on the feeding behavioral response of mosquitoes (Diptera: Culicidae) in the field in Tanzania. Parasites Vectors 2008b;1:42..

32. Tawatsin A, Wratten S, Scott R, Thavara U, Techadamrongsin Y. Repellency of volatile oils from plants against three mosquito vectors. J Vector Ecol. 2001;26:76-82.

33. Gaddaguti1 V, Rao TV, Rao AP. Potential mosquito repellent compounds of Ocimum speciesagainst 3N7H and 3Q8I of Anopheles gambiae. Biotech. 2016;6:26-33.

34. Carroll SP, Loye J. PMD, a registered botanical mosquito repellent with deet-like efficacy. J Am Mosq Control Assoc. 2006;22:507-14.

35. Curtis C, Lines J, Lu B, Renz A. Natural and synthetic repellents. In Appropriate Technology in Vector Control,Curtis CF, editor. CRC Press: Boca Raton; 1990. p. 75-92.

36. Ongore D, Kamunvi F, Knight R, Minawa A. A study of knowledge, attitudes and practices (KAP) of a rural community on malaria and the mosquito vector. East Afr Med J. 1989;66(Suppl 2):79-89. 
37. Aikins M, Pickering H, Alonso P, D'Alessandro U, Lindsay S, Todd J, Greenwood B. A malaria control trial using insecticide-treated bed nets and targeted chemoprophylaxis in a rural area of The Gambia, West Africa. 4. Perceptions of the causes of malaria and of its treatment and prevention in the study area. Trans R Soc Trop Med Hyg. 1993;87(Suppl 2):25-30.

38. Rutledge L, Collister D, Meixsell V, Eisenberg G. Comparative sensitivity of representative mosquitoes (Diptera: Culicidae) to repellents. J Med Entomol. 1983;20:506-10.

39. Schreck CE. Protection from blood-feeding arthropods. In: Wilderness Medicine: Management of Wilderness and Environmental Emergencies. (Auerbach, P.S. ed.) 3rd ed. St. Louis Mosby; 1995. p. 813-830.

40. Bhoopendra S, Prakash R, Manoj K. Toxicity of a plant based mosquito repellent/killer. Interdiscip Toxicol. 2012;5(Suppl 4):184-91.

41. Craveiro A, Fernandes A, Andrade C, Matos F, Alencar J, Machado M. ÓleosEssenciais de Plantas do Nordeste. Fortaleza: UFC; 1981.

42. Shaaya E, Kostjukovski M, Eilberg J, Sukprakarn C. Plant oils as fumigants and contact insecticides for the control of stored-product insects. J Stored Prod Res. 1997;33:7-15. 